\title{
STUDI PENERAPAN CRITICAL PATH METODE (CPM) PADA PROYEK PEMBANGUNAN PABRIK SEMEN REMBANG PT SEMEN GRESIK
}

\author{
Wasito \\ STIE Muhammadiyah Tuban \\ wasitoaq@gmail.com \\ Ahmad Yani Syaikhudin \\ Universitas Islam Darul Ulum Lamongan \\ ahyani@unisda.ac.id
}

\begin{abstract}
The process of planning and project control during the execution of the construction project work is an important part of the project. Because time is limited by the project management work schedules are determined so that the leaders involved in the project should be able to anticipate changes in conditions. The failure of a project can be caused by poor planning and control are less effective, so that the project activity is not efficient. Doing so may result in delay time, declining quality, and the rising cost of implementation. Conversely, careful planning and effective control will bring the project to success.Critical path method (CPM) is one option that is right for project management to control the project completion time effective and efficient. In order to reduce the impact of delays and cost overruns of the project budget can be done with three alternative acceleration process control; (I) Addition of labor, (ii) Overtime, (iii) Subcontract. Acceleration duration is done on the works is in the critical path.
\end{abstract}

Keywords: Planning, Controlling, Project Management, CPM Method, Acceleration.

\begin{abstract}
ABSTRAK
Proses perencanaan dan pengendalian proyek selama pelaksanaan pekerjaan proyek konstruksi merupakan bagian penting dari suatu proyek. Karena waktu kerja manajemen proyek dibatasi oleh jadwal yang ditentukan sehingga pimpinan yang terlibat dalam proyek harus dapat mengantisipasi perubahan kondisi yang terjadi. Kegagalan suatu proyek dapat disebabkan oleh perencanaan yang kurang baik serta pengendalian yang kurang efektif, sehingga kegiatan proyek tidak efisien. Hal tersebut dapat mengakibatkan keterlambatan waktu, menurunnya kualitas dan meningkatnya biaya pelaksanaan. Sebaliknya, perencanaan yang matang serta pengendalian yang efektif membawa proyek menuju keberhasilan. Metode Critical path (CPM) merupakan salah satu opsi yang tepat bagi manajemen proyek untuk mengendalikan waktu penyelesaian proyek yang efektif dan efisien. Untuk dapat mengurangi dampak keterlambatan dan pembengkakan biaya dari anggaran proyek dapat di lakukan proses percepatan dengan tiga alternatif pengendalian; (i) Penambahan tenaga kerja, (ii) Kerja lembur, (iii) Subkontrak. Percepatan durasi dilakukan pada pekerjaan - pekerjaan yang ada dalam lintasan kritis.
\end{abstract}

Kata Kunci: Perencanaan, Pengendalian, Manajemen Proyek, Metode CPM, Percepatan. 


\section{PENDAHULUAN \\ Latar Belakang}

Indonesia mau meninggalkan menjadi kategori negara berkembang, dengan ditandai pembangunan infrastruktur hampir di seluruh wilayah Indonesia, yang terlihat adalah pembangunan ruas jalan baru, jembatan sertan bangunan penghubung antar wilayah di Indonesia. Tentunya semua proyek tersebut membutuhkan bahan-bahan bangunan yang tidak sedikit khususnya komoditas semen. Dari sini timbul tingginya demand sehingga bepengaruh pada timbulnya Supply terhadap komoditi tersebut, dan itu merupakan peluang sekaligus tatangan yang harus dihadapi para perusahaan semen nasional (Soeharto, 2010). Keberhasilan ataupun kegagalan dari pelaksanaan sering kali disebabkan kurang terencananya kegiatan proyek serta pengendalian yang kurang efektif, sehingga kegiatan proyek tidak efisien, hal ini mengakibatkan keterlambatan, menurunnya kualitas pekerjaan, dan membengkaknya biaya pelaksanaan. Keterlambatan penyelesaian proyek sendiri merupakan suatu kondisi yang sangat tidak dikehendaki, karena hal ini dapat merugikan semua pihak baik dari segi waktu maupun biaya. Dalam kaitannya dengan waktu dan biaya produksi, perusahaan yang terlibat harus bias merencanakan waktu yang seefisien mungkin dalam setiap kegiatan atau aktivitas, sehingga biaya dapat diminimalkan dari rencana semula.

PT Semen Gresik (Semen Indonesia Group) merupakan perusahaan semen milik Negara, Semen Indonesia Group merupakan pemain nomor satu dalam industri semen nasional. Dengan Kapasitas produksi paling besar dibandingkan kompetitornya,Akhir tahun 2012, Semen Indonesia mengakuisisi Thang Long Cement, Vietnam, sehingga kapasitas produksinya langsung bertambah 2,3 juta ton/tahun. Kini, kapasitas produksi Semen Indonesia mencapai 31.8 juta ton per tahun. Saat ini PT Semen Gresik sedang membangun pabrik semen baru berkapasitas 3 juta ton per dengan anggaran mencapai 4.5 triliyun, yang berlokasi di kabupaten Rembang Jawa Tengah. Dengan tambahan pabrik baru di Rembang, Sumatera Barat, serta pabrik-pabrik baru lainnya, kelompok perusahaan semen terbesar di Indonesia ini mempunyai kapasitas 36,5juta ton per tahun.

Proyek pembangunan pabrik baru ini di rencanakan selesai pada 30 september 2016,Namun dalam pelaksanaannya, proyek mengalami keterlambatan yang disebabkan oleh terlambatnya perolehan Ijin Pinjam Pakai Kawasan Hutan (IPPKH) dari PERHUTANI untuk lahan pembangunan Facility Area Limestone Crusher.Durasi pekerjaan di area Limestone Crusher sendiri pada perencanaannya akan dikerjakan dengan durasi 10 bulan sedangkan actualnya hanya mempunyai waktu 4 bulan. Sehingga penjadwalan proyek mengalami perubahan/penyesuaian dan diperlukan suatu upaya percepatan durasi proyek.Oleh karena itu diperlukan analisis optimalisasi durasi proyek sehingga dapat diketahui berapa lama suatu proyek tersebut diselesaikan dan mencari adanya kemungkinan percepatan waktu pelaksanaan proyek dengan metode CPM (Critical Path Method / Metode Jalur Kritis). 


\section{LANDASAN TEORI}

\section{Critical Path Method(CPM)}

Metode CPM adalah metode yang digunakan untuk merencanakan dan mengendalikan proyek, yang merupakan sistem yang paling banyak digunakan diantara semua sistem lain yang memakai prinsip pembentukan jaringan. CPM dapat memperkirakan waktu yang dibutuhkan untuk melaksanakan setiap kegiatan dan dapat menentukan prioritas kegiatan yang harus mendapat perhatian pengawasan yang cermat. Metode CPM lebih terkenal dengan istilah Jalur kritis, yang memungkinkan terbentuknya suatu jalur atau lintasan yang memerlukan perhatian khusus (kritis). Tujuan lintasan kritis adalah untuk mengetahui dengan cepat kegiatan-kegiatan yang tingkat kepekaannya tinggi terhadap keterlambatan pelaksanaan.

Dalam sistem CPM ditentukan dua buah perkiraan waktu dan biaya untuk setiap aktivitas yang terdapat dalam jaringan. Kedua perkiraan ini adalah perkiraan normal dan perkiraan cepat. Perkiraan waktu normal merupakan perkiraan waktu yang paling mungkin. Biaya normal merupakan biaya yang diperlukan untuk menyelesaikan proyek dengan waktu normal. Perkiraan waktu cepat adalah waktu yang dibutuhkan suatu proyek jika biaya yang dikeluarkan tidak menjadi masalah dalam usaha untuk mempersingkat waktu bagi proyek tersebut. Jadi biaya mempercepat adalah biaya yang dibutuhkan untuk melaksanakan sautu pekerjaan yang dipercepat selesainya.

Untuk membuat jaringan kerja, harus diketahui dahulu semua kegiatan yang terjadi pada suatu proyek, waktu (durasi) setiap kegiatan, dan ketergantungan antar kegiatan (kegiatan pendahulu / predecessors) dan kegiatan pengikut / successors). Setiap kegiatan harus diketahui kegiatan pendahulu serta kegiatan pengikutnya. Pada CPM, metode yang dipakai adalah Activity on Arrow (AOA) dimana kegiatan dan durasi diletakkan pada tanda panah. Di bawah ini adalah Elemen-elemen di dalam CPM:

a) Anak panah (arrow) : Kegiatan

Anak Panah melambangkan kegiatan, pada umumnya sebuah anak panah berarti hanya mewakili satu kegiatan yg dicantumkan diatas anak panah, dan durasi kegiatan dicantumkan dibawah anak panah. Awal busur panah dinyatakan sebagai permulaan kegiatan dan mata panah sebagai akhir kegiatan. Terdapat tiga jenis anak panah:

$\longrightarrow$ Anak panah biasa menunjukkan suatu kegiatan yang dapat dikerjakan secara normal.

$\longrightarrow$ Anak panah tebal menunjukkan suatu kegiatan yang harus menjadi perhatian (kritis).

$\rightarrow$ Anak panah putus-putus menunjukkan kegiatan semu (dummy) 
b) Lingkaran kecil (Node) : peristiwa atau event

Node/ lingkaran melambangkan peristiwa, selalu digambarkan berupa lingkaran yang tebagi atas tiga ruang, ruang sebelah kiri merupakan Event,ruang sebelah kanan atas merupakan nomer hari dimana saat paling awal suatu event yg mungkin terjadi atau Earliest Event Time (EET), sedangkan ruang sebelah kanan bawah merupakan saat paling lambat dimana suatu event akan terjadi atau Latest Event Time (LET).

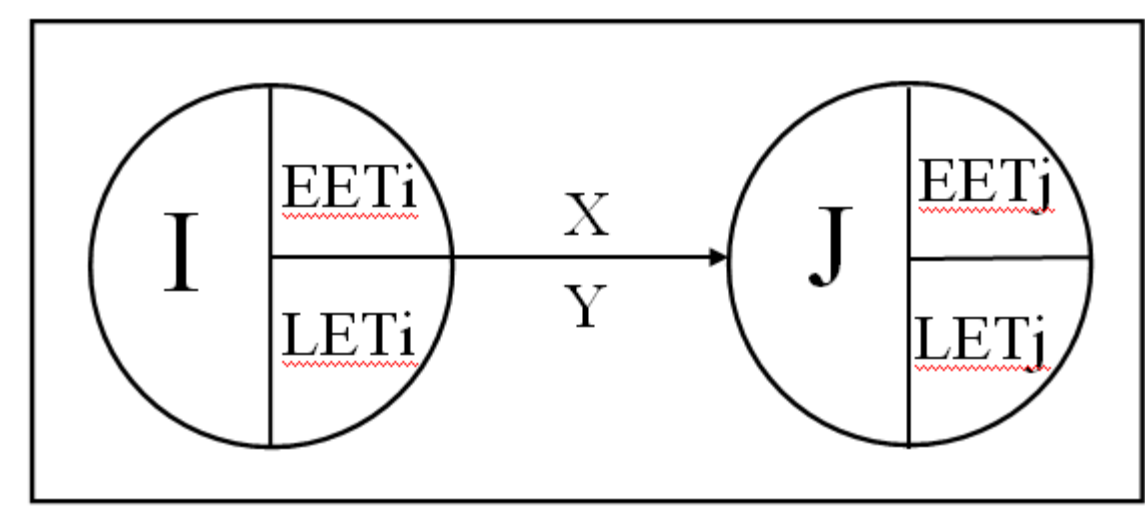

Dimana:

Gambar 2.4 Diagram AOA

I.J = Nomor peristiwa (event)

$\mathrm{X}=$ Nama kegiatan

EET $=$ Earliest Event Time

LET = Latest Event Time

$\mathrm{Y} \quad=$ Durasi kegiatan

Adapun prosedur perhitungan CPM dilakukan dengan 2 macam metode, yaitu:

1. Perhitungan Maju

Perhitungan maju digunakan untuk menghitung nilai EET (Earliest Even Time) dan mengidentifikasi jalur kritis. Kecuali kegiatan awal atau milestone, Suatu kegiatas baru dapat dimulai apabila kegiatan yang mendahuluinya (predecessor) telah selesai. Adapun rumus pehitungan maju adalah:

$$
E E T j=(E E T i+D i j) \max
$$

\section{Hitungan Mundur}

Perhitungan mundur dimaksudkan untuk mengetahui waktu atau tanggal paling akhir dapat memulai dan mengakhiri masing-masing kegiatan, tanpa menunda kurun waktu penyelesaian proyek secara keseluruhan, yang telah dihasilkan dari hitungan maju. Perhitungan mundur ini digunakan untuk menghitung LET (Latest Event Time), 
dimulai dari ujung paling kanan (hari penyelesaian proyek) dari jaringan kerja proyek.

\section{$L E T i=(L E T j-D i j) \min$}

c) Lintasan Kritis dan Float

Lintasan kritis adalah lintasan sepanjang diagram jaring yang mempunyai waktu terpanjang (durasi proyek) dan merupakan lintasan yang melalui kegiatan-kegiatan yang tidak mempunyai float (waktu jeda). Untuk menentukan lintasan kritis dari jaringan kerja dapat dilakukan dengan:

Lintasan yang melalui kegiatan-kegiatan yang mempunyai jumlah durasi terpanjang (Longest Path).

$\checkmark$ Dengan menghitung kegiatan-kegiatan yang mempunyai nilai Total Float $=0$

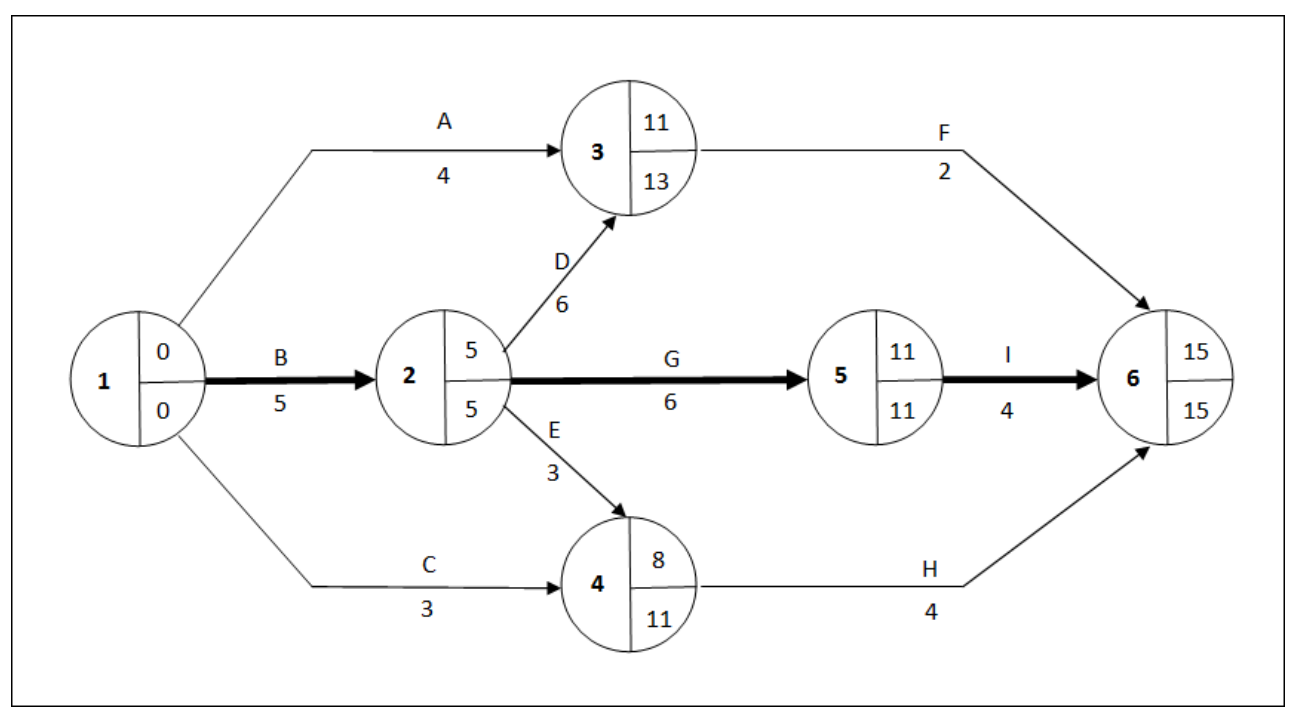

Gambar 2.5 Jaringan CPM

Float adalah batas toleransi keterlambatan suatu kegiatan yang dapat dimanfaatkan untuk optimasi waktu dan alokasi sumber daya. Ada tiga macam jenis Float, yaitu:

a) Total Float (TF) :

Jumlah waktu yang diperkenankan suatu kegiatan boleh ditunda, tanpa mempengaruhi jadwal penyelesaian proyek secara keseluruhan.

$$
T F=L E T(j)-E E T(i)-D(i-j)
$$

b) Free Float (FF) :

Sejumlah waktu dimana penyelesaian kegiatan tersebut dapat ditunda tanpa mempengaruhi waktu mulai paling awal dari kegiatan berikutnya ataupun semua peristiwa yang lain pada jaringan kerja. 


$$
F F=E E T(j)-E E T(i)-D(j-i)
$$

Apabila nilai free float sama dengan 0, hal ini berarti bahwa kegiatan tersebut tidak boleh ditunda pelaksanaannya karena apabila ditunda akan menyebabkan keterlambatan pada kegiatan berikutnya (Successor)

c) Interferent Float (IF):

Suatu kegiatan yang boleh digeser atau dijadwalkan dan merupakan selisih dari Total Float (TF) dengan Free Float (FF), serta sedikitpun tidak sampai mempengaruhi penyelesaian proyek secara keseluruhan.

$$
\boldsymbol{I F}=\boldsymbol{T F}-\boldsymbol{F F}
$$

Berikut ini adalah perbandingan Manajemen biaya tradisional dengan konsep Earn Value

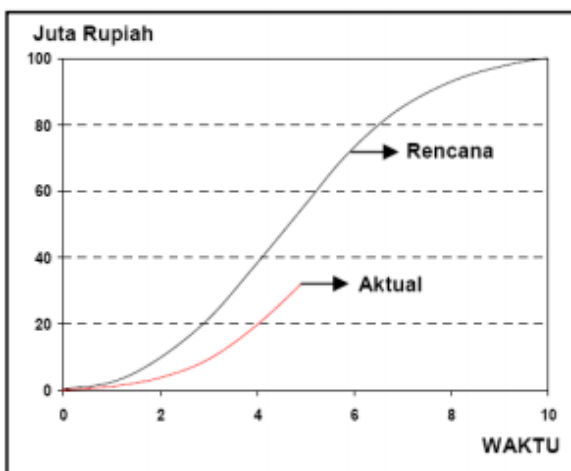

a. Manajemen Biaya Tradisional

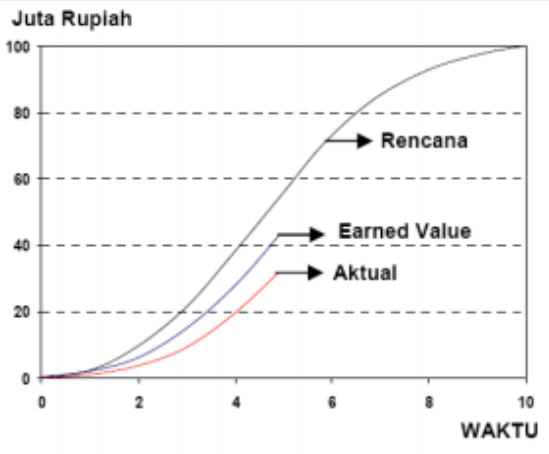

b. Konsep Earned Value

Perbandingan Manajemen biaya tradisional dengan konsep Earn Value (Soemardi, 2013)

Penggunaan konsep earned value dalam penilaian kinerja proyek dijelaskan melalui Gambar dibawah. Beberapa istilah yang terkait dengan penilaian ini adalah Cost Variance, Schedule Variance, Cost Performance Index, Schedule Performance Index, Estimate at Completion, dan Variance at Completion. 


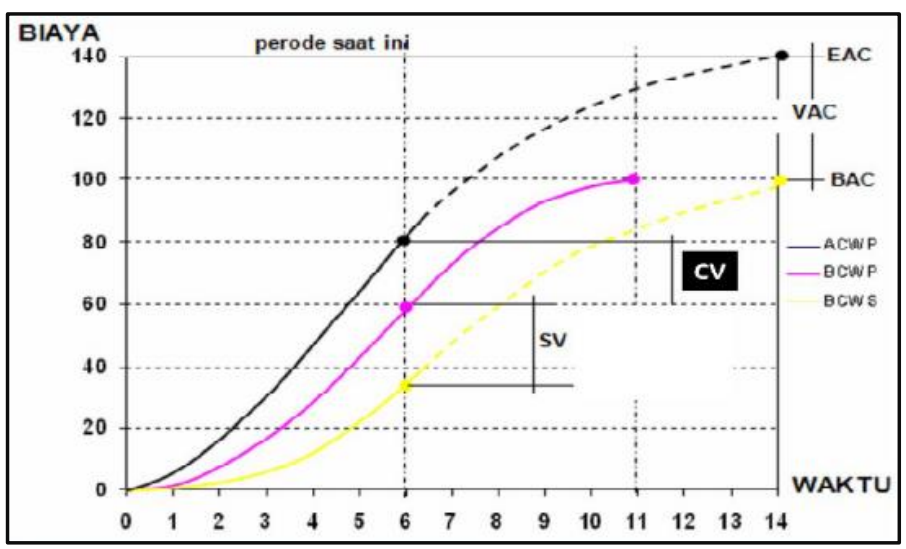

Gambar 2.7. Grafik kurva S Earned Value (Soemardi, 2013)

Sedangkan dibawah ini adalah grafik kombinasi SV dan CV pada beberapa kondisi yang berbeda.
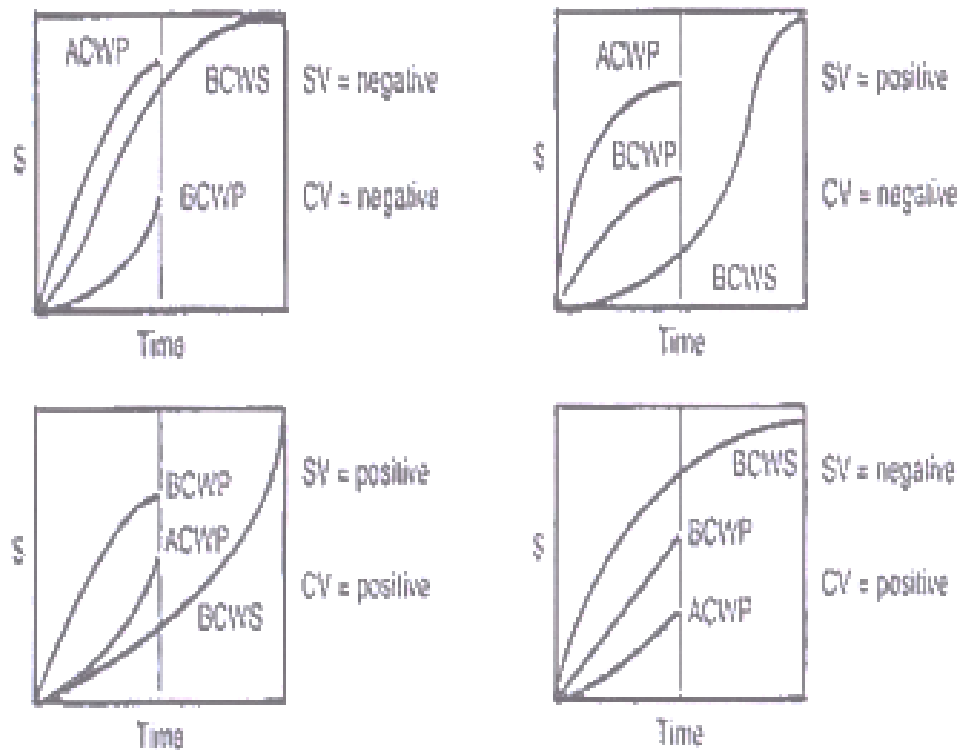

Gambar 2.8. Grafik Kombinasi CV (Cost Variance) dan SV (Schedule Variance) (Abrar, 2009)

\section{METODE PENELITIAN}

Menurut (Sugiyono, 2013), Metode penelitian pada dasarnya merupakan cara ilmiah untuk mendapatkan data dengan tujuan dan kegunaan tertentu. Berdasarkan hal tersebut terdapat empat kata kunci yang perlu diperhatikan yaitu cara ilmiah, data, tujuan dan kegunaan. Menurut (Darmadi, 2013), cara ilmiah berarti kegiatan penelitian itu didasarkan pada ciri-ciri keilmuan yaitu rasional, empiris, dan sistematis. Berdasarkan pemaparan di atas dapat disimpulkan bahwa metode penelitian adalah suatu cara ilmiah untuk memperoleh data dengan tujuan dan kegunaan tertentu. 


\section{A. Kerangka Pemikiran}

Dua ukuran kesuksesan proyek adalah waktu dan biaya untuk penyelesaian pekerjaan proyek yang memenuhi batas waktu dan biaya yang telah disepakati dalam dokumen perencanaan atau dokumen kontrak pekerjaan yang bersangkutan. Pada pelaksanaan proyek sering kali terjadi penambahan waktu kerja proyek yang tidak sesuai dengan rencana proyek. Hal dapat disebabkan oleh waktu dalam tahap pelaksanaanpekerjaan konstruksi proses perijinan hinggaIsu lingkungan. Dalam pelaksanaannya banyak pihak yang terlibat dalam penyelesaian proyek sehingga terdapat kompleksitas manajemen proyek pelaku konstruksi. Hal ini menyebabkan manajemen proyek sering kali tidak berjalan dengan baik dan dapat menyebabkan progress pelaksanaan menjadi terhambat.

Selanjutnya pada penelitian ini akan mengidentifikasi proses pengendalian pelaksanaan proyek konstruksi, yang mempengaruhi kinerja waktu dengan mengidentifikasi jalur kritis pada schedule pembangunan Proyek Pembangunan Pabrik Semen Rembang PT Semen Gresik.

\section{B. Hipotesis}

Akibat dari manajemen proyek yang kurang tepat dalam pelaksanaan Proyek Pembangunan Pabrik Semen Rembang PT Semen Gresik dapat menimbulkan permasalahan-permasalahan yang dapat menurunkan produktivitas kerja khususnya permasalahan yang mempengaruhi kinerja waktu, contohnya: Koordinasi antara pemilik/owner, konsultan, kontraktor, isu lingkungan dan Instansi terkait Perijinan berjalan kurang baik.

Berdasarkan latar belakang masalah, tujuan penelitian, landasan teori dan kerangka konseptual yang dirumuskan, maka hipotesis penelitian yang akan diajukan adalah sebagai berikut :

\section{"Jika faktor manajemen proyek dan dampak risiko telah diidentifikasi maka} akan dapat ditentukan tindakan penanganan pada penyimpangan kinerja waktu pada proyek Pembangunan pabrik semen rembang PT Semen Gresik".

Untuk membuktikan hipotesis penelitian, digunakan jenis pertanyaan yang disesuaikan dengan metode penelitian, yaitu sebagai berikut :

$\checkmark$ Faktor - faktor apa saja yang dapat mempengaruhi kinerja waktu dalam pelaksanaan proyek?

$\checkmark$ Apa saja dampak risiko yang akan timbul jika penanganan suatu masalah proyek tidak tepat?

$\checkmark$ Bagaimana menangani faktor-faktor yang dapat menyebabkan penyimpangan waktu pada proyek konstruksi, baik tindakan pencegahan maupun tindakan koreksi?

\section{Data Primer}

Data yang diperoleh dari sumber data pertama atau tangan pertama dilapangan. Sumber data dalam penelitian ini didapatkan dari wawancara dan studi kasus sebagai teknik pencarian dan pengumpulan informasi dilakukan dengan mendatangi secara 
langsung kepada pihak-pihak terkait, dalam hal ini orang- orang yang berkompeten dalam proyek yang mempunyai pengalaman minimal 10 tahun untuk dimintai keterangan segala sesuatu yang diketahuinya.

Studi kasus dilakukan dengan mengumpulkan sebanyak mungkin data yang didapat langsung dari lokasi proyek yang dapat digunakan untuk meneliti, menguraikan dan menjelaskan secara komprehensif berbagai aspek individu ataupun kelompok secara sistematis. Data yang diperoleh dengan teknik wawancara digunakan untuk memperkuat informasi yang diperoleh dari data proyek dan memformulasikan permasalahan yang dihadapi untuk di jadikan bahan menyusun hasil penelitian dan kesimpulan.

Wawancara dan studi kasus digunakan untuk mendapatkan informasi dari jajaran manajemen proyek dan konsultan proyek untuk diolah sebagai data yang diperlukan tersebut. Untuk mempersiapkan bahan petanyaan wawancara perlu dipersiapkan pedoman tentang wawancara, pengamatan atau daftar pertanyaan. Dalam pemilihan digunakan strategi dengan mempertimbangkan tiga faktor, yaitu:

$\checkmark$ Jenis pertanyaan yang diajukan

$\checkmark$ Pengendalian terhadap peristiwa yang diteliti

$\checkmark$ Tingkat kefokusan dan kesamaan penelitian yang berjalan/pernah dilakukan.

Ada bermacam-macam strategi penelitian sesuai dengan perumusan masalah yang ada, seperti tabel 3.1. dibawah ini :

Tabel 3.1 Strategi penelitian untuk masing-masing situasi

\begin{tabular}{|c|c|c|c|}
\hline Strategi & $\begin{array}{c}\text { Jenis Pertanyaan yang } \\
\text { akan digunakan }\end{array}$ & $\begin{array}{c}\text { Kendali terhadap } \\
\text { peristiwa yang } \\
\text { diteliti }\end{array}$ & $\begin{array}{c}\text { Fokus terhadap } \\
\text { kegiatan yang sedang } \\
\text { berjalan }\end{array}$ \\
\hline Survey & $\begin{array}{c}\text { Siapa,apa,dimana,bera } \\
\text { pa banyak,berapa besar }\end{array}$ & Ya & Ya \\
\hline Analisa Arsip & $\begin{array}{c}\text { Siapa,apa,diamana,ber } \\
\text { apa banyak, berapa } \\
\text { besar }\end{array}$ & Tidak & Ya \\
\hline Sejarah & Bagaimana,Mengapa & Tidak & Tidak \\
\hline Studi Kasus & Bagaimana,Mengapa & Tidak & Ya \\
\hline
\end{tabular}

Pada penelitian ini, penulis menggunakan riset kualitatif. Riset kualitatif bertujuan untuk menjelaskan sedalam-dalamnya melalui pengumpulan data. Riset ini tidak mengutamakan besarnya populasi atau sampling, bahkan populasi atau sampling sangat terbatas. Disini yang lebih ditekankan adalah persoalan kedalaman (kualitas) data bukan 
banyaknya (kuantitas) Berdasarkan metodologi kualitatif, ada beberapa metode riset, antara lain :

$\checkmark$ Metode Focus Group Discussion

$\checkmark$ Metode Wawancara

$\checkmark$ Metode Observasi

$\checkmark$ Metode Studi Kasus.

Keunggulan dari metode studi kasus, antara lain: Hasilnya dapat mendukung studistudi yang lebih besar dikemudian hari, ataupun dapat memberikan hipotesis-hipotesis untuk riset lanjutan. Sedangkan kelemahan dari metode ini adalah kajian menjadi kurang luas, sulit untuk digeneralisasikan dengan keadaan yang berlaku umum dan cenderung subjektif karena objek riset dapat mempengaruhi prosedur riset yang harus dilakukan. Pada pelaksanaanya, peneliti mencari data dengan mensurvey faktor-faktor apa saja yang berkembang dan yang mempengaruhi kinerja waktu dalam proses pelaksanaan proyek konstruksi pembangunan pabrik semen rembang PT Semen Gresik, dengan cara wawancara kepada pihak-pihak terkait yang dijadikan sumber informasi. Data-data yang didapat nantinya kemudian dikumpulkan dan dianalisa untuk mengetahui faktor-faktor manajemen proyek yang mempengaruhi kinerja waktu pelaksanaan proyek konstruksi pembangunan pembangunan pabrik semen rembang PT Semen Gresik dengan langkahlangkah seperti pada gambar flow chart berikut:

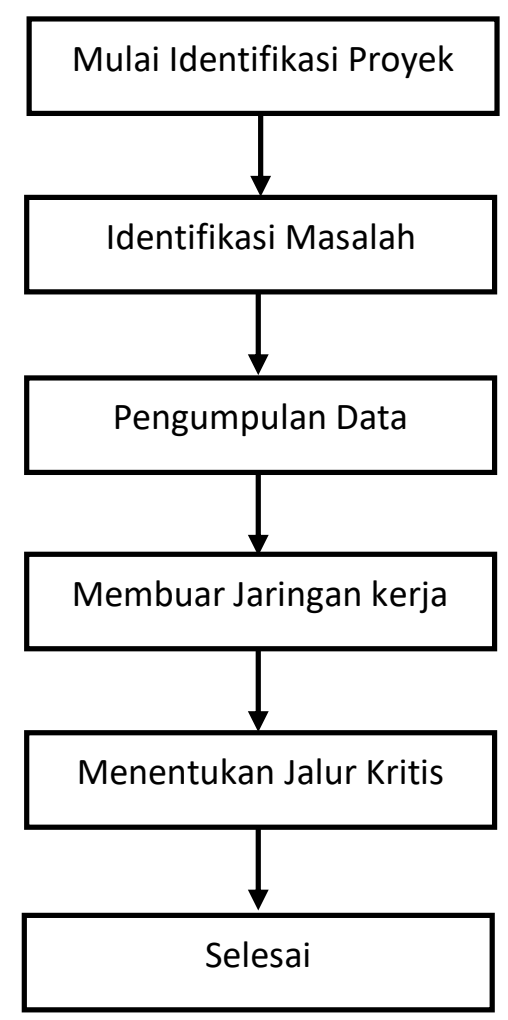

Gambar 3.1. Flow Chart 


\section{Model Penelitian}

Dalam penelitian yang dilakukan penulis mempunyai model penelitian yang bersifat deskriptif. Metode deskriptif adalah suatu metode dalam meneliti status sekelompok manusia, obyek, suatu sistem pemikiran ataupun suatu kelas peristiwa pada masa sekarang.

Tujuan dari penelitian deskriptif adalah untuk membuat deskripsi, gambaran atau lukisan secara sistematis, faktual dan akurat mengenai fakta-fakta, sifat serta hubungan antar kegiatan. Penelitian yang bersifat deskriptif mencoba untuk mencari suatu uraian yang menyeluruh dan teliti dari suatu keadaan. Adapun langkah-langkah dalam penelitian deskriptif, sebagai berikut:

- Memilih dan merumuskan masalah

- Menentukan tujuan dari penelitian yang dikerjakan.

- Memberikan batasan dari area penelitian

- Merumuskan kerangka teori

- Menelusuri sumber-sumber kepustakaan

- Merumuskan hipotesa-hipotesa yang ingin diuji

- Membuat tabulasi serta analisa statistik

- Memberikan interpretasi

- Mengadakan generalisasi serta deduksi dari penemuan serta hipotesa-hipotesa yang ingin diuji

- Membuat laporan penelitian secara ilmiah

Keadaan yang dihadapi disini adalah adanya perbedaan umur pelaksanaan proyek dengan umur rencana proyek yang telah ditetapkan. Umur rencana proyek biasanya lebih pendek daripada umur pelaksanaan proyek. Optimalisasi waktu yang dilakukan adalah mempercepat durasi proyek dengan penambahan biaya yang seminimal mungkin. Salah satu metode mempercepat durasi proyek dalam istilah asingnya adalah crashing. Menurut (Wardhani, 2018), terminologi proses crashing adalah dengan mereduksi durasi suatu pekerjaan yang berpengaruh terhadap waktu penyelesaian proyek. Proses crashing dipusatkan pada kegiatan yang berada pada lintasan kritis. Percepatan durasi dapat dilakukan pada kegiatan-kegiatan yang dilalui oleh lintasan kritis. Ada beberapa metode mempercepat suatu kegiatan, sehingga didapat alternatif terbaik sesuai dengan kondisi kontraktor pelaksana. Cara-cara tersebut misalnya:

- Perubahan hubungan logika ketergantungan antar kegiatan

- Menambah sumber daya manusia

- Melaksanakan kerja lembur

- Menambah atau mengganti peralatan

- Menambah ketersediaan material

Hal tersebut tentunya menambah biaya. Penambahan biaya ini akan memberikan suatu besaran perbedaan biaya akibat percepatan waktu sesuai dengan banyak waktu percepatannya, dalam hal ini optimalisasi waktu dibatasi oleh peningkatan biaya maksimal $1 \%$ dari total biaya. Tehnik analisis yang digunakan dalam penelitian ini adalah 
dengan menggunakan pendekatan CPM. Estimasi waktu penyelesaian suatu proyek dapat diketahui dengan metode Single duration estimate atau perkiraan waktu (durasi) tunggal untuk setiap Kegiatan.

Menurut (Render, 2013), CPM membuat asumsi bahwa waktu kegiatan diketahui pasti, hingga hanya diperlukan satu faktor waktu untuk tiap kegiatan. Pada CPM dipakai "deterministik", yaitu memakai satu angka estimasi. Jadi, disini kurun waktu untuk menyelesaikan pekerjaan dianggap diketahui, kemudian pada tahap berikutnya, diadakan pengkajian lebih lanjut untuk memperpendek kurun waktu, misalnya dengan menambah biaya atau time cost trade-off atau crash program. Dalam menganalisis proses crashing digunakan asumsi berikut:

1. Jumlah sumber daya yang tersedia tidak merupakan kendala. Ini berarti dalam menganalisis program mempersingkat waktu, alternatif yang dipilih tidak dibatasi oleh tersedianya sumber daya.

2. Bila diinginkan waktu penyelesaian lebih cepat, maka sumber daya bertambah. Sumber daya ini dapat berupa tenaga kerja, material peralatan, atau bentuk lainnya yang dapat dinyatakan dalam sejumlah pendanaan.

Sistematika dari proses penyusunan jaringan kerja (network) adalah sebagai berikut:

1. Mengkaji dan mengidentifikasi lingkup proyek, menguraikan, memecahkannya menjadi kegiatan-kegiatan atau kelompok kegiatan yang merupakan komponen proyek.

2. Menyusun kembali komponen-komponen pada butir 1 , menjadi mata rantai dengan urutan yang sesuai logika ketergantungan.

3. Memberikan perkiraan kurun waktu bagi masing-masing kegiatan yang dihasilkan dari penguraian lingkup proyek.

4. Mengidentifikasi jalur kritis (critical path) dan floatpada jaringan kerja.

Untuk menentukan waktu penyelesaian proyek, maka harus diidentifikasi yang disebut jalur kritis. Jalur (path) merupakan serangkaian aktivitas berhubungan yang bermula dari node awal ke node penyelesaian/ akhir. Untuk menyelesaikan proyek, semua jalur harus dilewati. Oleh karena itu, harus ditentukan jumlah waktu yang dibutuhkan berbagai jalur tersebut. Jalur terpanjang yang melewati, menentukan total watu yang dibutuhkan untuk menyelesaikan proyek. Jika aktivitas pada jalur terpanjang itu ditunda, maka seluruh proyek mengalami keterlambatan. Aktivitas jalur terpanjang merupakan aktivitas jalur kritis, dan jalur terpanjang itu disebut jalur kritis. Setelah jalur kritis diketahui, langkah selanjutnya adalah melakukan percepatan proyek. Langkahlangkahnya adalah sebagai berikut:

1. Menentukan waktu percepatan dan menghitung biaya tambahan untuk percepatan setiap kegiatan.

2. Mempercepat waktu penyelesaian proyek dengan mengutamakan kegiatan kritis yang memiliki slope biaya terendah. Apabila upaya percepatan 
dilakukan pada aktivitas-aktivitas yang tidak berada pada lintasan kritis, maka waktu penyelesaian keseluruhan tidak berkurang.

3. Susun kembali jaringan kerjanya.

4. Ulangi langkah kedua dan berhenti melakukan upaya percepatan apabila terjadi pertambahan lintasan kritis. Apabila terdapat lebih dari satu lintasan kritis, maka upaya percepatan dilakukan serentak pada semua aktivitas yang berada pada lintasan kritis. Usahakan agar tidak terjadi penambahan atau pemindahan jalur kritis apabila diadakan percepatan durasi pada salah satu kegiatan.

5. Upaya percepatan dihentikan apabila aktivitas-aktivitas pada lintasan kritis telah jenuh seluruhnya (tidak mungkin ditekan lagi).

6. Hitung biaya keseluruhan akibat percepatan untuk mengetahui total biaya proyek yang dikeluarkan.

Aspek biaya dalam penjadwalan proyek diperhitungkan karena adanya hubungan ketergantungan antara durasi waktu dengan biaya. Biaya yang dihitung adalah biaya langsung.

\section{PEMBAHASAN}

\section{Menghitung Jalur Kritis}

Definisi jalur kritis menurut salah satu penemu CPM adalah: If there is a path from origin to terminus whose length equals the duration of the schedule, it is called a critical-path.

(Kelley, 2010)

Dengan kata lain total waktu jalur kritis akan sama dengan umur proyek. Hal ini berarti jalur kritis adalah jalur yang memiliki waktu terpanjang dari semua jalur yang dimulai dari peristiwa awal sampai peristiwa yang terakhir dalam activity network diagram. Oleh karena itu, jalur kritis menunjukkan kegiatan-kegiatan kritis di dalam proyek. Maksudnya, suatu kegiatan disebut dengan kegiatan kritis apabila suatu delay atau penundaan waktu di suatu kegiatan akan mempengaruhi waktu penyelesaian keseluruhan dari proyek. Oleh karena itu, kegiatan disebut tidak kritis bila kegiatan ini mempunyai delay. Delay pada kegiatan tidak kritis disebut slack atau float time (waktu mengambang).Konsep float sangat berharga karena memberikan fleksibilitas atau "ruang manuver" pada penjadwalan untuk menyelesaikan tugas-tugas tertentu sehingga ada suatu periode waktu di mana kegiatan dapat meleset tetapi tidak mempengaruhi jalur kritis dan tanggal penyelesaian. Menurut Hendrickson \& Tung (2008), terdapat tiga kategori float, yaitu:

- Free float adalah banyaknya delay yang dapat ditugaskan untuk setiap satu kegiatan tanpa menunda kegiatan selanjutnya. Free float, $F F_{i j}$ untuk aktivitas $(i, j)$ adalah:

$$
F F_{i j}=E_{j}-E_{i}-D_{i j}
$$

- Independent float adalah banyaknya delay yang dapat ditugaskan untuk setiap satu kegiatan tanpa menunda kegiatan selanjutnya atau membatasi 
penjadwalan kegiatan sebelumnya. Independen float, $F F_{i j}$, untuk kegiatan $(i, j)$ dihitung sebagai berikut:

$$
\boldsymbol{I} \boldsymbol{F}_{\boldsymbol{i} \boldsymbol{j}}=\boldsymbol{E}_{\boldsymbol{j}}-\boldsymbol{L}_{\boldsymbol{i}}-\boldsymbol{D}_{\boldsymbol{i} \boldsymbol{j}}
$$

- Total float adalah maksimum banyaknya delay yang dapat ditugaskan untuk setiap kegiatan tanpa menunda keseluruhan proyek. Total Float, $T F_{i j}$, untuk setiap kegiatan $(i, j)$ dihitung sebagai berikut:

$$
T F_{i j}=L_{j}-E_{i}-D_{i j}
$$

Secara grafis, ketiga macam float time dan slack time diilustrasikan pada contoh Gambar berikut:
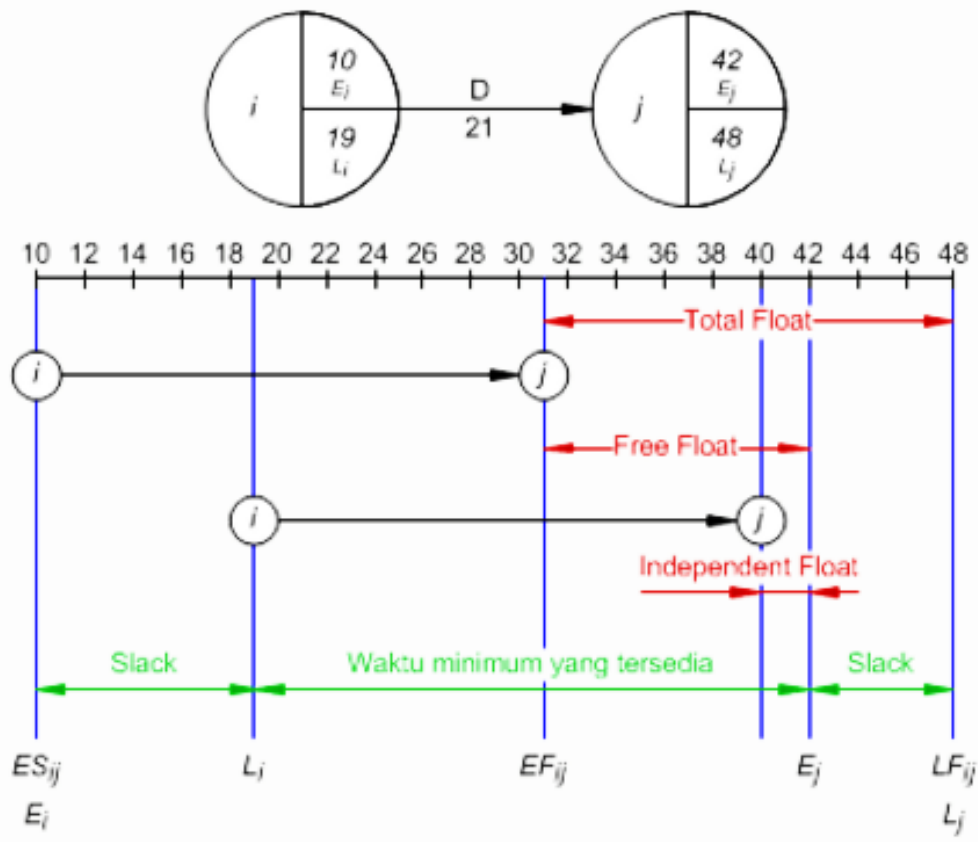

Gambar 4.5 Ilustrasi contoh Float Time dan Slack time

Berdasarkan hasil analisa dengan perhitungan-perhitungan diatas dapat digambarkan Activity network diagram dari penjadwalan proyek area Limestone Crusher pabrik semen gresik di rembang, dengan cara menelusuri jalur terpanjang dari awal sampai akhir proyek yakni jalur yang melalui node denganEET sama dengan LET, seperti pada gambar 4.5 dibawah ini: 


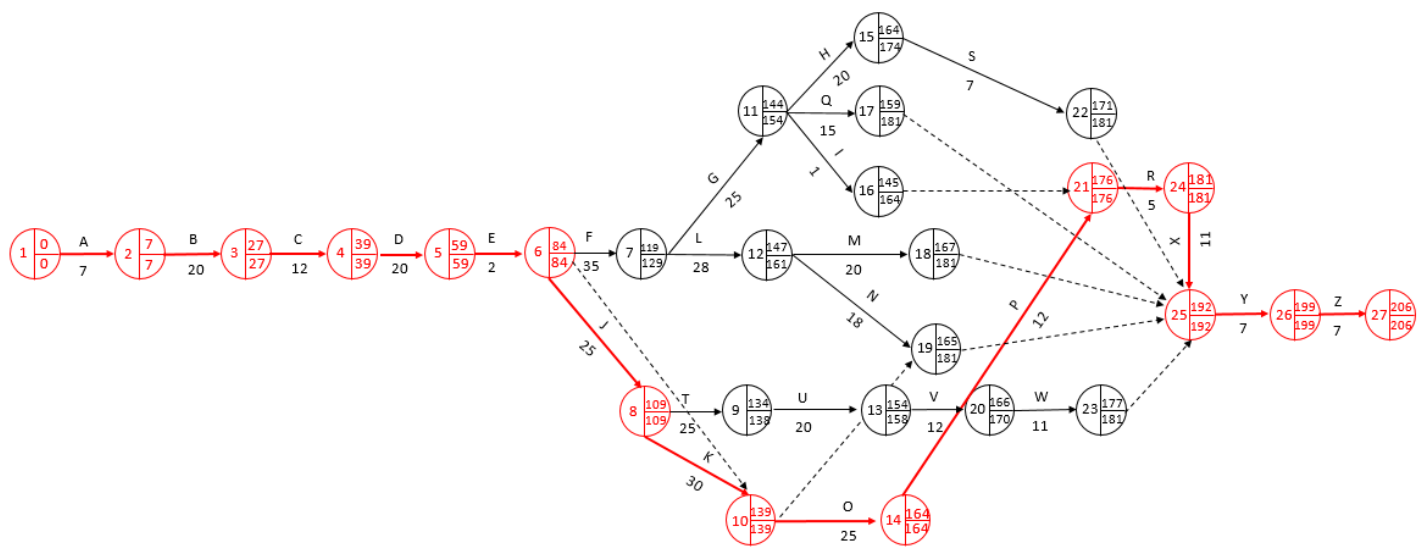

Gambar 4.6 Jalur kritis dalam Activity Network Diagram

Dapat di lihat bahwa node yang menjadi jalur kritis adalah node yang berwarna merah yaitu aktivitas A,B,C,D,E,J,K,O,P,X,Y dan Z, karena tidak memiliki waktu delay.Aktivitas pekerjaan yang menjadi jalur kritis berpotensi menyebabkan waktu penyelesaian proyek Delay. Sedangkan delay di jalur tidak kritis mungkin tidak akan menunda waktu penyelesaian proyek sejauh delay tidak melebihi slack dan float time untuk masing-masing kegiatan tidak kritis. Dalam suatu activity network diagram memungkinkan ditemui lebih dari satu jalur kritis, bahkan semua jalur memungkinkan untuk menjadi jalur kritis. Jalur kritis memiliki kepekaan sangat tinggi atas keterlambatan penyelesaian suatu proyek. Keterlambatan pada jalur ini akan memperlambat penyelesaian waktu proyek secara keseluruhan, meskipun kegiatan lain tidak mengalami keterlambatan. Manajemen dapat melakukan percepatan penyelesaian proyek secara keseluruhan dengan mempercepat waktu penyelesaian pekerjaan-pekerjaan di jalur kritis. Jalur kritis juga dapat berubah sebagai akibat dari keterlambatan atau percepatan penyelesaian kegiatan.

Berikut ini adalah tabel analisa jalur kritis: 
Tabel 4.2 Perhitungan EET dan LET

\begin{tabular}{|c|c|c|c|c|c|c|c|c|}
\hline \multirow{2}{*}{ No. } & \multirow{2}{*}{$\begin{array}{c}\text { Kegiatan } \\
\quad(i, j)\end{array}$} & \multirow{2}{*}{$\begin{array}{c}\text { Durasi, } \\
D_{i j}\end{array}$} & \multicolumn{2}{|c|}{ EET } & \multicolumn{2}{|c|}{ LET } & \multirow{2}{*}{$\begin{array}{c}\begin{array}{c}\text { Earliest } \\
\text { start time, }\end{array} \\
E S_{i j}=E_{i}\end{array}$} & \multirow{2}{*}{$\begin{array}{c}\begin{array}{c}\text { Latest start } \\
\text { time, }\end{array} \\
L S_{i j}=L_{j}-D_{i j}\end{array}$} \\
\hline & & & $E_{i}$ & $E_{j}$ & $L_{i}$ & $L_{j}$ & & \\
\hline 1 & $\mathrm{~A}(1,2)$ & 7 & 0 & 7 & 0 & 7 & 0 & 0 \\
\hline 2 & $\mathrm{~B}(2,3)$ & 20 & 7 & 27 & 7 & 27 & 7 & 7 \\
\hline 3 & $\mathrm{C}(3,4)$ & 12 & 27 & 39 & 27 & 39 & 27 & 27 \\
\hline 4 & $\mathrm{D}(4,5)$ & 20 & 39 & 59 & 39 & 59 & 39 & 39 \\
\hline 5 & $\mathrm{E}(5,6)$ & 25 & 59 & 84 & 59 & 84 & 59 & 59 \\
\hline 6 & $\mathrm{~F}(6,7)$ & 35 & 84 & 119 & 84 & 126 & 84 & 91 \\
\hline 7 & $\mathrm{G}(7,11)$ & 25 & 119 & 144 & 126 & 156 & 119 & 131 \\
\hline 8 & $\mathrm{H}(11,15)$ & 20 & 144 & 164 & 156 & 176 & 144 & 156 \\
\hline 9 & $\mathrm{I}(11,16)$ & 1 & 144 & 145 & 156 & 164 & 144 & 163 \\
\hline 10 & $\mathrm{~J}(6,8)$ & 25 & 84 & 109 & 84 & 109 & 84 & 84 \\
\hline 11 & $\mathrm{~K}(8,10)$ & 30 & 109 & 139 & 109 & 139 & 109 & 109 \\
\hline 12 & $\mathrm{~L}(7.12)$ & 28 & 119 & 126 & 147 & 161 & 119 & 133 \\
\hline 13 & $\mathrm{M}(12,18)$ & 20 & 147 & 161 & 167 & 181 & 147 & 161 \\
\hline 14 & $\mathrm{~N}(12,19)$ & 18 & 147 & 161 & 165 & 181 & 147 & 163 \\
\hline 15 & $\mathrm{O}(10,14)$ & 25 & 139 & 164 & 139 & 164 & 139 & 139 \\
\hline 16 & $\mathrm{P}(14,21)$ & 12 & 164 & 176 & 164 & 176 & 164 & 164 \\
\hline 17 & $\mathrm{Q}(11,17)$ & 15 & 144 & 156 & 159 & 181 & 144 & 166 \\
\hline 18 & $\mathrm{R}(21,24)$ & 5 & 176 & 181 & 176 & 181 & 176 & 176 \\
\hline 19 & $\mathrm{~S}(15,22)$ & 7 & 164 & 176 & 171 & 181 & 164 & 174 \\
\hline 20 & $\mathrm{~T}(8,9)$ & 25 & 109 & 134 & 109 & 138 & 109 & 113 \\
\hline 21 & $\mathrm{U}(9,13)$ & 20 & 134 & 138 & 154 & 158 & 134 & 138 \\
\hline 22 & $\mathrm{~V}(14,20)$ & 12 & 154 & 158 & 166 & 170 & 154 & 158 \\
\hline 23 & $\mathrm{~W}(20,23)$ & 11 & 166 & 170 & 167 & 181 & 166 & 170 \\
\hline 24 & $X(24.25)$ & 11 & 181 & 192 & 181 & 192 & 181 & 181 \\
\hline 25 & $Y(25,26)$ & 7 & 192 & 199 & 192 & 199 & 192 & 192 \\
\hline 26 & $\mathrm{Z}(26,27)$ & 7 & 199 & 206 & 199 & 206 & 199 & 199 \\
\hline
\end{tabular}


Tabel 4.3 Perhitungan Activity Float Time

\begin{tabular}{|c|c|c|c|c|c|c|c|c|c|}
\hline \multirow{2}{*}{ No. } & \multirow{2}{*}{$\begin{array}{c}\text { Kegiatan } \\
(i, j)\end{array}$} & \multirow{2}{*}{ Durasi, $D_{i j}$} & \multicolumn{2}{|c|}{ EET } & \multicolumn{2}{|c|}{ LET } & \multirow{2}{*}{$\begin{array}{l}\text { Free } \\
\text { Float }\end{array}$} & \multirow{2}{*}{$\begin{array}{l}\text { Indp. } \\
\text { Float }\end{array}$} & \multirow{2}{*}{$\begin{array}{l}\text { Total } \\
\text { Float }\end{array}$} \\
\hline & & & $E_{i}$ & $E_{j}$ & $L_{i}$ & $L_{j}$ & & & \\
\hline 1 & $\mathrm{~A}(1,2)$ & 7 & 0 & 7 & 0 & 7 & 0 & 0 & 0 \\
\hline 2 & $\mathrm{~B}(2,3)$ & 20 & 7 & 27 & 7 & 27 & 0 & 0 & 0 \\
\hline 3 & $C(3,4)$ & 12 & 27 & 39 & 27 & 39 & 0 & 0 & 0 \\
\hline 4 & $\mathrm{D}(4,5)$ & 20 & 39 & 59 & 39 & 59 & 0 & 0 & 0 \\
\hline 5 & $\mathrm{E}(5,6)$ & 25 & 59 & 84 & 59 & 84 & 0 & 0 & 0 \\
\hline 6 & $\mathrm{~F}(6,7)$ & 35 & 84 & 119 & 84 & 126 & 0 & 0 & 7 \\
\hline 7 & $\mathrm{G}(7,11)$ & 25 & 119 & 144 & 129 & 154 & 0 & -10 & 10 \\
\hline 8 & $\mathrm{H}(11,15)$ & 20 & 144 & 164 & 154 & 176 & 0 & -10 & 12 \\
\hline 9 & $\mathrm{I}(11,16)$ & 1 & 144 & 145 & 154 & 164 & 0 & -10 & 19 \\
\hline 10 & $\mathrm{~J}(6,8)$ & 25 & 84 & 109 & 84 & 109 & 0 & 0 & 0 \\
\hline 11 & $\mathrm{~K}(8,10)$ & 30 & 109 & 139 & 109 & 139 & 0 & 0 & 0 \\
\hline 12 & $\mathrm{~L}(7.12)$ & 28 & 119 & 147 & 129 & 161 & 0 & -10 & 14 \\
\hline 13 & $\mathrm{M}(12,18)$ & 20 & 147 & 167 & 161 & 181 & 0 & -14 & 14 \\
\hline 14 & $\mathrm{~N}(12,19)$ & 18 & 147 & 165 & 161 & 181 & 0 & -14 & 16 \\
\hline 15 & $\mathrm{O}(10,14)$ & 25 & 139 & 164 & 139 & 164 & 0 & 0 & 0 \\
\hline 16 & $\mathrm{P}(14,21)$ & 12 & 164 & 176 & 164 & 176 & 0 & 0 & 0 \\
\hline 17 & $\mathrm{Q}(11,17)$ & 15 & 144 & 159 & 154 & 181 & 0 & -10 & 22 \\
\hline 18 & $\mathrm{R}(21,24)$ & 5 & 176 & 181 & 176 & 181 & 0 & 0 & 0 \\
\hline 19 & $\mathrm{~S}(15,22)$ & 7 & 164 & 171 & 174 & 181 & 0 & -10 & 10 \\
\hline 20 & $\mathrm{~T}(8,9)$ & 25 & 109 & 134 & 109 & 138 & 0 & 0 & 4 \\
\hline 21 & $\mathrm{U}(9,13)$ & 20 & 134 & 154 & 138 & 158 & 0 & -4 & 4 \\
\hline 22 & $\mathrm{~V}(14,20)$ & 12 & 154 & 166 & 158 & 170 & 0 & -4 & 4 \\
\hline 23 & $\mathrm{~W}(20,23)$ & 11 & 166 & 177 & 170 & 181 & 0 & -4 & 4 \\
\hline 24 & $\mathrm{X}(24.25)$ & 11 & 181 & 192 & 181 & 192 & 0 & 0 & 0 \\
\hline 25 & $Y(25,26)$ & 7 & 192 & 199 & 192 & 199 & 0 & 0 & 0 \\
\hline 26 & $\mathrm{Z}(26,27)$ & 7 & 199 & 206 & 199 & 206 & 0 & 0 & 0 \\
\hline
\end{tabular}

\section{SIMPULAN DAN SARAN}

SIMPULAN

1. Dengan menggunakan CPM dapat diketahui jangka waktu pelaksanaan proyek pekerjaan area limestone crusherpabrik Semen Gresik dirembang yaitu selama 206 hari kalender, dengan jalur kriteis terletak pada pekerjaan excavation work, concrete work, erection mechanical belt conveyor, crusher, 
casing \& ducting bag filter, screw conveyor, rotary feeder, termination, pre commissioning dan commissioning.

2. Untuk untuk membuat Activity Network Diagramsecara manual matematis cukup rumit karena item pekerjaan yang banyak dan kompleks. Namun saat ini banyak software yang menyediakan fasilitas untuk mendapatkan CPM. Di Proyek Semen rembang sendiri menggunakan software Primavera Project Management dan Microsoft Project.

3. Proyek pembangunan area limestone crusher mengalami keterlambatan akibat terlambatnya perolehan ijin PPKH. Untuk mengantisipasi dan mengatasi keterlamabatan dengan upaya percepatan waktu penyelesaian proyek, manajemen proyek dari awal telah menganggarkan budget untuk tenaga kerja dan peralatan pendukung proses percepatan, sehingga tidak perlu merubah scope dan menambah nilai kontrak masing-masing kontraktor yang telah di tender-kan dan tidak mengalami pembengkakan biaya.

SARAN

1. Dalam setiap pekerjaan manajemen harus selalu mengontrol pekerjaan terutama yang ada dalam lintasan kritis dengan disiplin kerja sesuai dengan jadwal rencana kerja aktivitas agar pekerjaan tetap berjalan sesuai dengan rencana.

2. Untuk proyek jaringan yang berskala besar perlu dilakukan penyederhanaan jaringan untuk mempermudah perhitungan lintasan kritis.

3. Meningkatkan koordinasi antar bagian terkait dalam pelaksanaan proyek, Catatan atau record terhadap penyebab keterlambatan, action plan, minute of project implementatiom sangatlah dibutuhkan untuk koreksi dan perencanaan proyek-proyek sejenis dimasa mendatang, catatan tersebut tidak hanya mencakup hal teknis saja melainkan juga yang bersifat administrasi terutama yang berkaitan dengan kontrak kerja.

\section{DAFTAR PUSTAKA}

Abrar, H. (2009). Manajemen Proyek. Yogyakarta: Andi offset.

Darmadi, H. (2013). Metodologi Penelitian Pendidikan. Bandung: Alf beta.

Kelley. (2010). Manajemen Jalur Krisis. Jakarta: Salemba Empat.

Soeharto, I. (2010). Manajemen Proyek dari Konseptual Sampai Operasional. Jakarta: Erlangga.

Soemardi, B. W. (2013). Isu Strategis pada Pengadaan Pengusahaan Jalan Tol dalam

Kerjasama Pemerintah dan Swasta. Jurnal Teoretis Dan Terapan Bidang Rekayasa

Sipil, 20, 233-244. Retrieved from

https://www.researchgate.net/publication/337071175_Isu_Strategis_pada_Pengadaan_P engusahaan_Jalan_Tol_dalam_Kerjasama_Pemerintah_dan_Swasta

Render, H. \&. (2013). Manajemen Operasi. Jakarta: Salemba Empat.

Sugiyono. (2013). Metodologi Penelitian Kuantitatif Kualitatif dan R\&D. Bandung:

Alfabeta.

Wardhani, K. d. (2018). Pengaruh Corporate Governance Terhadap Kinerja Perusahaan di Indonesia. Seminar Nasional Sains dan Teknologi. 